\title{
A Produção Decisória do Sistema de Justiça Criminal para o Crime de Homicídio: Análise dos Dados do Estado de São Paulo entre 1991 e 1998*
}

\author{
Ludmila Ribeiro
}

\section{INTRODUÇÃO}

$\mathrm{O}$ propósito deste artigo é analisar a produção decisória do sistema de justiça criminal do Estado de São Paulo para os crimes de homicídio processados entre os anos de 1991 e 1998. O ponto de sustentação empírico desta análise é o banco de dados da Fundação Sistema Estadual de Análise de Dados (Seade), o qual possui informações policiais e judiciais acerca dos casos de homicídio ocorridos no Estado de São Paulo entre 1991 e 1998: abertura de processo, sentença e condenação. Essa base foi escolhida por ser um sistema de informações resultante da interligação dos sistemas oficiais de informação da Polícia Civil e do Judiciário para o período privilegiado.

Assim, apesar dos problemas dessa base de dados - discutidos ao longo deste artigo -, essa fonte se mostrou adequada para a apresentação dos caminhos que um delito pode percorrer desde o seu registro na polícia até o seu sentenciamento pelo Judiciário. Para a melhor compreensão de tais caminhos, cumpre destacar o que está sendo considerado sistema de justiça criminal para fins desta análise. Essa expressão pode

\footnotetext{
* Este artigo é parte da pesquisa Metodologia de Tratamento do Tempo e da Morosidade Processual na Justiça Criminal, realizada no âmbito do Concurso Nacional de Pesquisas Aplicadas em Segurança Pública e Justiça Criminal, coordenado por Joana Domingues Vargas, e do qual pude participar como pesquisadora.
}

DADOS - Revista de Ciências Sociais, Rio de Janeiro, vol. 53, nº̂1, 2010, pp. 159 a 193. 


\section{Ludmila Ribeiro}

ser entendida como a conexão entre as polícias (Militar e Civil), o Ministério Público, a Defensoria Pública, o Judiciário e o Sistema Prisional, no intuito de processar as condutas capituladas como crime no Código Penal Brasileiro (CPB), de acordo com os procedimentos legais estabelecidos no Código de Processo Penal (CPP). Esse arranjo pode ser mais bem vislumbrado na Figura 1, que apresenta a sistemática de funcionamento da justiça criminal brasileira.

\section{Figura 1}

Sistemática de funcionamento da justiça criminal brasileira ${ }^{1}$

Papel de cada instituição em uma organização linear no momento em que ela atua

\section{Polícia Militar}

Acionada pelo 190, é a primeira, em geral, a tomar conhecimento do crime, dado querealiza a atividade de policiamento ostensivo.



Realiza o inquérito policial, que é um procedimento administrativo que objetiva a apuração do crime e de seu autor.



\section{Ministério Público}

É o órgão responsável pela acusação formal, realizando a denúncia, que é a peça a partir da qual se diz iniciado o processo penal.



\section{Defensoria Pública}

Instituição estatal constituida para viabilizar a assistência judicial a todos os cidadãos que não podem pagar um advogado particular.

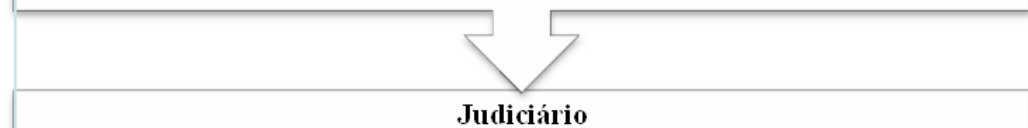

A partir de suas Varas Criminais e dos Tribunais do Júri (exclusivos para crimes dolosos contra a vida), realiza procedimentos legais destinados ao adequado julgamento do crime.

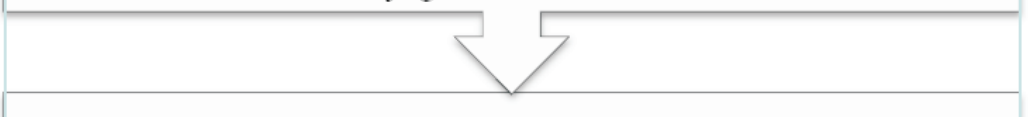

\section{Sistema prisional}

Encarcera todos os indivíduos que, ao final do processo criminal, receberam uma pena privativa de liberdade. 
A Figura 1 denota que a movimentação do sistema de justiça criminal brasileiro se inicia a partir da operação da organização encarregada de selecionar, no campo social, os acontecimentos cujas características permitem a sua categorização como um crime. Essa primeira organização é a Polícia Militar, a qual atende os chamados telefônicos da população "denunciando" a ocorrência de um crime e também realiza o patrulhamento ostensivo, momento em que se pode deparar com diversas atividades criminosas, registrando-as prontamente.

A Polícia Militar, que não tem atribuições investigativas, deve comunicar a ocorrência do suposto crime à Polícia Civil, à qual cabe verificar se a queixa tem fundamento e, nesse caso, buscar indícios e evidências da autoria e da materialidade do delito (Sapori, 2007). À fase policial segue-se a processual, que tem início com a denúncia formalizada pelo Ministério Público. A essa peça se seguem o interrogatório do preso, a oitiva das testemunhas e a defesa prévia realizada pela Defensoria Pública ou por um advogado particular.

A fase judicial, por sua vez, culmina em uma sentença que absolve ou condena o suspeito de um determinado crime. Essa sentença pode ser proferida pelo juiz singular ${ }^{2}$ ou pelo júri (específica para os crimes dolosos contra a vida). Na hipótese de o desfecho do caso ser a condenação, o caso é encaminhado para o sistema penitenciário, o qual administra uma série de estabelecimentos que têm como objetivo prover as condições mínimas para que o sentenciado cumpra a sua pena privativa de liberdade.

A ideia deste estudo é, portanto, analisar o fluxo da produção decisória no processamento dos casos de homicídio que tiveram lugar no Estado de São Paulo no período compreendido entre 1991 e 1998. Para tanto, este artigo está dividido em três seções, além desta introdução e da conclusão. A primeira é destinada a apresentar os problemas relacionados à coleta de informações sobre processamento judicial no Brasil e mostrar como isso interfere na escolha da metodologia que pode ser utilizada para a reconstituição do fluxo decisório do sistema de justiça criminal. Em seguida, tem-se a apresentação da base de dados analisada em todos os seus aspectos, bem como as taxas de esclarecimento, sentenciamento e condenação para o delito de homicídio. Ainda nessa seção, a forma de construção da base de dados utilizada neste artigo é problematizada. O intuito é apontar a riqueza desse sistema de informações e os seus principais problemas, a fim de questionar em que me- 
dida esses resultados podem ser generalizados para o Brasil contemporâneo. A terceira seção descreve os modelos estatísticos construídos com o objetivo de compreender quais são os fatores (legais e extralegais) que aumentam ou diminuem a probabilidade de um caso de homicídio perpassar as fases de esclarecimento, sentenciamento e condenação no âmbito do fluxo do sistema de justiça criminal paulistano entre 1991 e 1998.

\section{O QUE SÃO ESTUDOS SOBRE FLUXO DO SISTEMA DE JUSTIÇA CRIMINAL? FONTES DE DADOS, METODOLOGIA, POSSIBILIDADES E LIMITES DESSAS ANÁLISES}

Uma das temáticas mais relevantes no que se refere ao direito em ação é a relativa à capacidade do sistema judicial de processar as demandas que chegam ao seu conhecimento. Nesse cenário, as organizações policiais, as promotorias e os tribunais de justiça emergem com particular importância, uma vez que são esses os órgãos responsáveis pela aplicação do direito.

A problemática atual dos sistemas de justiça criminal diz respeito à sua incapacidade de processar adequadamente os delitos que chegam ao seu conhecimento. Assim, estudos que visam à avaliação da produção decisória das organizações que compõem o sistema de justiça criminal emergem como análises de especial importância, visto que viabilizam o cálculo: 1) do percentual de casos que sobrevivem até a fase final do fluxo; e 2) dos determinantes da passagem de um caso da fase anterior para a subsequente (Misse e Vargas, 2007).

Essas informações são relevantes para a avaliação do trabalho realizado pelas organizações que compõem o sistema de justiça criminal, do ponto de vista da realização da ideia de justiça (não deixar que nenhuma lesão a direito, ou ameaça de lesão a direito, permaneça sem apreciação do sistema de justiça criminal), dado que permitem o cálculo das taxas apresentadas no Quadro 1 a seguir.

A partir dessas taxas, os estudos sobre o funcionamento do sistema de justiça criminal podem reconstituir o fluxo de processamento de crimes e verificar em que medida o processamento dos crimes acaba por ter um formato de funil, com muitos casos iniciados e poucos encerrados.

Essa reconstituição é importante porque, quanto maior a diferença (em termos percentuais) entre a base e o topo, maior a impunidade no cená- 


\section{Quadro 1}

Taxas que os estudos sobre fluxo do sistema de justiça criminal permitem calcular de acordo com a agência e com o significado das informações

\begin{tabular}{|c|c|c|}
\hline Taxa & Significado & Agência \\
\hline Esclarecimento & $\begin{array}{c}\text { Percentual de inquéritos esclarecidos, } \\
\text { considerando o total de ocorrências } \\
\text { registradas. }\end{array}$ & Polícia Civil \\
\hline Processamento & $\begin{array}{c}\text { Percentual de processos iniciados, } \\
\text { considerando o total de crimes registrados. } \\
\text { Percentual de processos iniciados, } \\
\text { considerando o total de ocorrências } \\
\text { registradas. } \\
\text { Percentual de processos iniciados, } \\
\text { considerando o total de inquéritos cuja } \\
\text { autoria fora esclarecida. }\end{array}$ & $\begin{array}{l}\text { Ministério } \\
\text { Público }\end{array}$ \\
\hline Sentenciamento & $\begin{array}{l}\text { Percentual de processos que alcançaram a fase } \\
\text { de sentença, considerando o total de } \\
\text { ocorrências registradas. } \\
\text { Percentual de processos que alcançaram a fase } \\
\text { de sentença, considerando o total de } \\
\text { processos iniciados. }\end{array}$ & Judiciário \\
\hline Condenação & $\begin{array}{l}\text { Percentual de condenações, considerando o } \\
\text { total de ocorrências registradas. } \\
\text { Percentual de condenações, considerando o } \\
\text { total de sentenças proferidas. }\end{array}$ & Judiciário \\
\hline
\end{tabular}

Elaboração da autora.

rio analisado, já que um grande número de lesão a direitos permanece sem o devido exame judicial.

Por outro lado, esses percentuais permitem ao pesquisador avaliar a eficiência do sistema no processamento das causas e ainda calcular a probabilidade de punição pela prática de um dado crime em um dado intervalo de tempo. Essas cifras, em última instância, seriam a maior avaliação do sistema e da sua capacidade dissuasória sobre a intenção de um dado cidadão em cometer o crime, visto que desvela a certeza (ou não) da punição pela transgressão de dadas regras.

Uma vez pontuada a utilidade dos estudos sobre fluxos, cumpre destacar o porquê de tais estudos não serem realizados com muita frequência no cenário brasileiro ${ }^{3}$. 
De acordo com a literatura especializada nessa área (Vargas e Ribeiro, 2008; Ribeiro, 2009), a carência de estudos sobre essa temática no Brasil se deve, basicamente, a quatro fatores: 1) ausência de um sistema integrado de informações; 2) existência de diferentes ritos processuais aplicáveis a diferentes crimes; 3 ) custos de operacionalização das pesquisas de acordo com o delito e a metodologia escolhida. Para a melhor compreensão desses fenômenos, esta seção foi subdividida em três subseções, e cada qual analisa uma dessas questões.

\section{Dificuldades Decorrentes da Ausência de um Sistema Integrado de Informações Criminais}

A principal dificuldade para a operacionalização de estudos sobre o sistema de justiça criminal no Brasil diz respeito à inexistência de um sistema oficial de estatística que congregue informações sobre todas as fases, desde a policial até a do sistema prisional. Isso ocorre porque, nessa realidade, as bases de dados são fragmentadas, produzidas por cada organização que compõe o sistema, de acordo com a sua própria lógica e de acordo com os documentos que interessam a essa fase de processamento, sem a preocupação com o desdobramento desse dado nas fases posteriores.

A ausência de um sistema integrado de informações estatísticas se torna ainda mais emblemática em um cenário no qual o pesquisador possui diversas dificuldades em coletar informações sobre a forma como cada uma das agências do sistema processa os casos que são levados ao seu conhecimento (Adorno e Izumino, 2000).

Na atualidade, apenas as agências que realizam as fases iniciais ou finais do fluxo possuem dados razoavelmente organizados para uma boa análise estatística e, por conseguinte, uma boa interpretação do que se passa no seu âmbito. Assim, a maioria dos estudos sobre funcionamento do sistema de justiça criminal que contam com análise estatística é aquela que tem como base ou o sistema de informações sobre mortalidade (que contabiliza informações sobre as vítimas), ou os sistemas das polícias civis e militares (que sumarizam as principais características sobre os autores ou suspeitos de autoria do fato delituoso e, em alguns casos, sobre as vítimas desses), ou ainda os sistemas de informações penitenciárias (Infopen) ${ }^{4}$ (que congregam informações sobre os detentos dos diversos estabelecimentos penais existentes nos estados). 
De acordo com Andrade, Peixoto e Moro (2003), o Sistema de Informações sobre Mortalidade (SIM) do Departamento de Informática do SUS (Datasus) oferece informações sobre o cenário de mortalidade no Brasil, de maneira desagregada (por município e unidade da federação), desde 1979. A fonte primária desse sistema é o atestado de óbito, no qual é registrada a causa do óbito segundo a classificação internacional de doenças (CID-10). Além da causa de mortalidade, existem ainda diversas outras informações sobre a vítima, mas que, em várias situações, não são bem preenchidas, inviabilizando o seu uso.

Os dados policiais, por sua vez, são de dois tipos: os disponibilizados nos boletins de ocorrência realizados pela Polícia Militar e os dados dos inquéritos policiais realizados pela Polícia Civil. As informações contidas nos boletins de ocorrência da Polícia Militar são bem mais limitadas que as informações contidas nos inquéritos da Polícia Civil, mas, em geral, são mais acessíveis, tendo, portanto, um maior grau de utilização pelos pesquisadores (Batitucci, 2008).

Por outro lado, os estudos que têm como base a porta de saída do fluxo geralmente utilizam como fonte de dados as informações das administrações penitenciárias de cada estado. Os sistemas penitenciários estaduais se consubstanciaram como fontes de dados para alguns trabalhos realizados nessa temática à medida que, ao longo dos anos $1980 \mathrm{e}$ 1990, foram realizados diversos censos penitenciários, reunindo dados bastante confiáveis sobre quem são os criminosos que perpassam todas as fases do sistema (Lemgruber, Cerqueira e Musumeci, 2000).

Contudo, a utilização apenas das informações relativas às fases iniciais e finais do fluxo do sistema de justiça criminal não permite o entendimento do que ocorre com os casos registrados na polícia até o momento em que eles ingressam no sistema prisional, ou ainda o que faz com que um caso seja encerrado em quaisquer das fases intermediárias desse processamento. Ou seja, apesar de esses dados permitirem o conhecimento do número de casos processados por uma das organizações que compõem o sistema de justiça criminal, eles não permitem conhecer os desdobramentos que esses mesmos casos tiveram nas organizações que ocupam posição subsequente no fluxo.

Diante dessas limitações, diversos estudiosos preferem construir as suas próprias bases de dados a partir da consulta sistemática aos documentos jurídicos e penais que viabilizam a compreensão do processamento de um delito pelo sistema de justiça criminal. Contudo, isso 
não significa que seja mais fácil obter e analisar as informações sobre esse problema. A primeira dificuldade encontrada pelos pesquisadores nesse sentido está relacionada à própria autorização que o gerente do sistema (ou do arquivo no qual esses documentos jurídico-penais se encontram armazenados) tem de conceder para que o pesquisador possa coletar os dados. No entanto, essas não são as únicas dificuldades encontradas pelos pesquisadores da área. Quando as barreiras superiores são vencidas, mediante expressa autorização das autoridades encarregadas de administrar o sistema de justiça criminal, há inúmeras outras que necessitam ser enfrentadas. Uma delas está relacionada ao poder de que os funcionários dos cartórios ou dos escritórios de documentação de cada uma das agências do sistema desfrutam. Em regra, esses funcionários não podem negar autorização superior. Contudo, caso não lhes interesse que o trabalho seja executado, pelas mais diferentes razões, eles criam obstáculos intransponíveis, que impedem o trabalho regular de coleta de dados. Não disponibilizam espaço, evitam atender às demandas formuladas, informam que hoje ou amanhã não será possível pesquisar, pois haverá um evento qualquer e o espaço somente estará disponível dentro de alguns dias, entre outras escusas (Adorno e Izumino, 2000).

Outro problema sério diz respeito à qualidade dos dados registrados nos documentos jurídico-penais. Em inúmeras situações, parece haver um esmero, até exagerado, no que concerne, por exemplo, às formalidades legais e administrativas. Tudo indica que, sobre elas, pesam os mais rigorosos controles. Em outras situações, porém, as informações são bastante precárias. De modo geral, salvo exceções, os processos judiciais não logram ir muito além do que foi apurado nos inquéritos policiais. Se os inquéritos policiais são mal elaborados, carentes de informações básicas que identifiquem a possível autoria de um crime, os processos judiciais também o são, não permitindo ao pesquisador compreender quais são os fatores que contribuem para que um determinado juiz venha a condenar ou absolver o caso.

Uma vez superados os obstáculos relacionados à coleta de informações que permitam a realização de pesquisas empíricas sobre o funcionamento do sistema de justiça criminal, iniciam-se os problemas relacionados à interpretação do que esses dados querem dizer e das realidades que eles revelam. No entanto, essas mesmas realidades podem ser diferenciadas, por exemplo, dependendo do crime em análise. 
As análises de fluxo não escapam a problemas dessa natureza, e, por isso, a literatura especializada nessa seara (Cano, 2006; Vargas, 2007; Vargas e Ribeiro, 2008) destaca que o primeiro passo para a realização de um estudo com esse propósito diz respeito à modalidade de delito a ser enfatizada.

\section{Dificuldades Decorrentes da Existência de Ritos Processuais Diferenciados, de acordo com a Natureza do Delito}

Segundo Vargas (2007), a primeira decisão a ser tomada pelo pesquisador na tentativa de reconstituição do fluxo de processamento de um delito no âmbito do sistema de justiça criminal brasileiro é a escolha do crime.

Nessa realidade, a escolha do crime é importante porque a legislação penal e processual penal brasileira estabelece ritos diferenciados, de acordo com a natureza do delito. Dentre os principais ritos existentes, cumpre destacar os seguintes: 1 ) os procedimentos processuais penais aplicáveis aos crimes punidos com reclusão; 2) os procedimentos processuais penais aplicáveis aos crimes punidos com detenção e prisão simples; e 3) os procedimentos aplicáveis aos crimes cuja pena máxima seja inferior a dois anos de prisão, os quais são processados de acordo com o previsto na Lei 9.099/95, que regulamenta o funcionamento dos Juizados Especiais Criminais.

O rito ordinário é o caminho percorrido pela maioria dos delitos existentes no âmbito do Código Penal e das legislações extravagantes. No entender de Sapori (1995), as fases que compõem esse rito podem ser sumarizadas a partir da seguinte linha de fluxo: interrogatório $\rightarrow$ defesa prévia $\rightarrow$ audiência de inquirição de testemunhas de acusação $\rightarrow$ audiência de inquirição de testemunhas de defesa $\rightarrow$ realização de diligências $\rightarrow$ alegações finais de acusação $\rightarrow$ alegações finais da defesa $\rightarrow$ sentença do juiz ${ }^{5}$.

Procedimento processual distinto, por sua vez, é aquele aplicado aos crimes dolosos contra a vida, sendo denominado rito do Tribunal do Júri. Nesse caso, na primeira fase do processamento, têm-se todos os atos processuais do rito ordinário, os quais são denominados sumário de culpa e implicam não uma sentença de condenação ou de absolvição, mas uma sentença de pronúncia que determina o julgamento do acusado pelo Tribunal do Júri. 


\section{Ludmila Ribeiro}

De acordo com Tourinho Filho (2001), essa sentença não analisa o mérito do processo ${ }^{6}$, pois, mesmo reconhecendo que seja o réu o autor do crime, não aplica nenhuma penalidade, tendo como propósito apenas encerrar a primeira fase do procedimento escalonado do júri. Vencida essa fase, tem-se o julgamento pelo júri propriamente dito, o qual se caracteriza por possuir uma sentença construída a partir de votos sim ou não de sete cidadãos a perguntas formuladas pelo juiz a partir das teses sustentadas pela defesa e pela acusação em plenário.

Já o procedimento aplicável aos crimes punidos com detenção e prisão simples é o rito sumaríssimo, caracterizado pela concentração dos atos processuais e pela oralidade. Nesses casos, após o recebimento da denúncia, seguem-se, na mesma audiência, o interrogatório do acusado e a audiência de instrução, debates e julgamento (Azevedo, 2008). Esses são os procedimentos vigentes no âmbito dos Juizados Especiais Criminais, os quais são responsáveis pelo processamento e pelo julgamento de casos a que a lei comine pena máxima não superior a dois anos de prisão (a partir da alteração inserida pela Lei 10.259/01), desde que tais crimes não se sujeitem a procedimento especial. Nessas instâncias, existe a possibilidade de acordos para a solução do caso por meio de modalidades outras que não a sentença que absolve ou condena o autor do delito.

Nos casos de crimes de competência dos Juizados Especiais Criminais, é dispensada a realização de inquérito policial e existe a possibilidade de conciliação entre vítima e autor do fato para a composição de danos, bem como a transação penal oferecida pelo Ministério Público para o cumprimento de pena alternativa sem reconhecimento de culpa e, ainda, a suspensão condicional do processo (id., ibid.).

Portanto, em razão dessa diversidade de procedimentos aplicáveis e, por conseguinte, de métodos para encerramento do processamento de um delito, os estudos sobre o fluxo de papéis e de pessoas no âmbito do sistema de justiça criminal devem centrar-se em apenas um tipo de delito. De maneira mais específica:

Se, de acordo com os códigos e com as atividades práticas dos operadores da Justiça Criminal, para cada tipo de delito corresponde uma maneira singular de tratamento dos casos, pode-se pensar que a natureza do delito intervém de maneira decisiva na configuração que o fluxo assume. Partindo deste pressuposto, comparar fluxos de diferentes cri- 
mes é menos elucidativo do que comparar fluxos de crimes de mesma natureza, tratados por diferentes sistemas de Justiça (Vargas, 2007:64).

Uma vez escolhido o delito para análise, inicia-se o terceiro problema a ser administrado pelo pesquisador: que metodologia empregar, considerando os custos e o tempo para a realização da pesquisa?

\section{Dificuldades que se Seguem aos Custos Decorrentes do Emprego de Cada Tipo de Metodologia}

No que se refere à metodologia de coleta e de análise de dados sobre o processamento de um dado delito, os estudos sobre fluxo do sistema de justiça criminal podem assumir três desenhos diferenciados: 1) longitudinal ortodoxo; 2) transversal; e 3) longitudinal retrospectivo.

O método tradicional de reconstituição do fluxo de papéis e de pessoas dentro do sistema de justiça criminal é o estudo longitudinal ortodoxo. Esse tipo de análise consiste no acompanhamento de um conjunto de ocorrências policiais de cada tipo de $\mathrm{crime}^{7}$, a partir dos seus registros de ocorrência, ao longo de certo período. Tal acompanhamento tem por objetivo verificar o percentual de casos que progride às fases subsequentes e ainda os que são arquivados antes do previsto. Esse acompanhamento individual e progressivo dos casos à medida que eles avançam nas diversas fases do sistema de justiça criminal permite contabilizar, diretamente, quantos e quais casos registrados na polícia se transformam em inquéritos policiais e, depois, em denúncias no Ministério Público, processos e sentenças no Judiciário (Cano, 2006).

Contudo, como os sistemas de informação das agências de segurança pública no Brasil não foram desenhados para monitorar o fluxo de casos ao longo de diversas instituições (Polícia, Ministério Público, Judiciário), cabe ao pesquisador acompanhar individualmente os casos, verificando in loco a passagem desses de uma fase a outra. Poucas são as situações em que o monitoramento pode ser realizado a partir da integração de bases de dados diferenciadas. Como cada instituição usa as suas próprias categorias e os seus próprios códigos de identificação, há uma dificuldade enorme de identificar qual é o desdobramento de um caso de um sistema em outro sistema.

Assim, a utilização da metodologia longitudinal ortodoxa fica condicionada à disponibilidade do pesquisador em acompanhar um determinado conjunto de casos durante certo espaço de tempo para ver o 
que acontece com esses casos. Exatamente por isso, geralmente, os estudos longitudinais ortodoxos fixam um limite até o qual o conjunto de casos será acompanhado - limite este, em geral, fixado em anos. Durante o período em que os pesquisadores acompanham o conjunto de casos, eles procuram registrar as passagens dos casos às fases subsequentes, as características do processo e ainda as razões para o encerramento do caso antes do previsto. A principal limitação à realização de estudos como esses diz respeito ao fato de demandarem muito investimento financeiro e temporal, já que o pesquisador deve acompanhar pessoalmente e durante um período razoável de tempo o que ocorre com aquele conjunto de casos.

Uma alternativa a esse estudo longitudinal ortodoxo é a aplicação de um desenho transversal que comece por calcular o número de casos de cada tipo de crime processados anualmente por cada uma das agências que compõem o sistema de justiça criminal. Em estudos como esse, a pesquisa consulta as agências para mensurar a sua produção decisória a partir de: número de ocorrências registradas pela polícia, número de inquéritos abertos, número de denúncias oferecidas, número de julgamentos realizados, número de sentenças e número de condenações (Cano, 2006).

A desvantagem do desenho transversal em relação ao longitudinal ortodoxo é a impossibilidade de se conhecer quais casos denunciados originalmente correspondem a que casos em cada uma das instituições subsequentes. Por exemplo, as denúncias por homicídio oferecidas pelos promotores em um ano correspondem a crimes cometidos durante vários anos, e, com isso, mudanças pontuais - por exemplo, uma força-tarefa para encerrar o processamento de todos os casos que se encontram em uma determinada vara criminal em um dado ano - não são captadas. Ou seja, o desenho transversal permite conhecer os números de crimes, inquéritos, denúncias, processos e sentenças de um ano, mas não permite saber quais peças são relativas a quais crimes praticados e em que anos. Isso provoca uma perda de precisão, particularmente nos estágios intermediários do sistema. Em contraste, o desenho transversal é muito mais simples de se desenvolver e permite trabalhar com o conjunto total dos casos em vez de apenas com uma amostra. Da mesma forma, essa estratégia permite trabalhar não apenas com um ano, mas com uma série temporal de vários anos. 
Até 1984, o método mais utilizado para a reconstituição do funil do sistema de justiça criminal era o longitudinal ortodoxo. Com o início da pesquisa anual da Organização das Nações Unidas (ONU), intitulada United Nations Surveys on Crime Trends and the Operations of Criminal Justice Systems, o desenho transversal passou a ser a base metodológica de estudos que tinham como objetivo avaliar a produção decisória dos sistemas de justiça criminal em uma perspectiva comparada. Tal survey consiste no repasse de um formulário à agência maior, encarregada da prevenção ao delito e ao controle da criminalidade em cada país, para que esta preencha o número de ocorrências registradas na polícia, o número de inquéritos policiais encerrados, o número de processos iniciados, o número de sentenças e o número de condenações segundo a natureza do delito e o ano de produção dessas peças. A partir dessas informações, a ONU pode calcular, para os mais diversos países, as taxas de esclarecimento, processamento, sentenciamento e condenação de cada sistema de justiça criminal ${ }^{8}$. Com a disseminação dos bancos de dados, o desenho transversal passou a ser a metodologia mais utilizada para a mensuração dessas taxas.

Por fim, há uma terceira metodologia, denominada longitudinal retrospectiva. Esse desenho pode ser entendido como a análise em profundidade dos casos encerrados em um determinado ano, no intuito de viabilizar o monitoramento do fluxo retrospectivamente - de trás para frente-, até chegar ao estágio inicial. Esse tipo de estudo é utilizado especialmente nas análises que têm como propósitos o cálculo do tempo e a melhor compreensão das características dos casos que alcançaram a fase de sentença. No entanto, na medida em que essa abordagem trabalha primordialmente com casos cujo processamento foi completo, visto que perpassou todas as fases do fluxo, esse tipo de metodologia termina por ser pouco comum aos estudos relacionados a fluxo, conformando-se como ponto de partida para os estudos que possuem como foco o tempo da justiça criminal.

Em resumo, apesar de a abordagem ortodoxa ser a mais adequada para a reconstituição do fluxo de papéis e de pessoas no âmbito do sistema de justiça criminal, as dificuldades relacionadas ao acompanhamento dos casos ao longo do seu fluxo no sistema têm colocado a utilização do desenho transversal, complementado com uma análise longitudinal retrospectiva de uma amostra de casos que chegam ao estágio final, como a alternativa mais viável para o entendimento do que ocorre na passagem do caso de uma fase a outra no âmbito do sistema de justiça 
criminal. Nesse momento, cumpre destacar que a base de dados da Fundação Seade, apesar de todos os problemas, é uma das poucas fontes de informação que congregam dados oficiais dentro de uma perspectiva longitudinal ortodoxa, sendo essa a razão da sua escolha para objeto desta análise.

\section{O FUNIL DA JUSTIÇA CRIMINAL PARA O DELITO DE HOMICÍDIO NO ESTADO DE SÃO PAULO - UMA RECONSTITUIÇÃO DO FLUXO DE PROCEDIMENTOS E DE PESSOAS A PARTIR DOS DADOS ORGANIZADOS PELA FUNDAÇÃO SEADE ${ }^{9}$}

Este artigo tem como propósito a análise do fluxo de procedimentos e de pessoas no âmbito da justiça criminal paulistana, e, para tanto, tem como foco o delito de homicídio. A fonte de informação utilizada é a base de dados montada pela Fundação Seade, a qual se refere aos casos de homicídio ocorridos em São Paulo entre 1991 e 1998 e aos seus respectivos desdobramentos judiciais.

Assumindo a perspectiva de análise longitudinal - ou seja, após a organização dos dados quantitativos produzidos pelo sistema de justiça criminal paulistano, no formato de um fluxo de decisões tomadas nas diferentes organizações de que aquele se compõe-, este estudo procurou reconstruir a trajetória dos indivíduos acusados pela prática do homicídio desde o seu indiciamento até a execução penal.

O banco de dados da Fundação Seade foi escolhido como objeto de análise por se constituir na compilação do sistema de informações criminais da Companhia de Processamento de Dados do Estado de São Paulo (Prodesp), a qual armazena as informações tanto do Instituto de Identificação como da Polícia Civil, do Judiciário e do Sistema Penitenciário do Estado de São Paulo. Em outras palavras, a base de dados do sistema de justiça criminal analisada neste artigo foi construída e organizada pela Fundação Seade segundo uma perspectiva longitudinal.

De acordo com Lima (2005), para a melhor compreensão da natureza dos dados existentes nessa base, é importante retomar a história da sua construção, a qual se iniciou em 1995, quando a Fundação Seade realizou um levantamento de todas as bases de dados existentes na Prodesp. No que se refere especificamente à área de segurança pública, esse órgão pôde constatar a existência de três bases de dados distintas sobre o sistema de justiça criminal: 1) uma referente à Polícia Civil, com dados sobre a data do crime e de encerramento do inquérito; 2 ) 
uma relativa ao Judiciário, com informações como as datas da denúncia, recursos e sentença final; e 3) uma referente à administração prisional, com dados sobre a data da expedição do guia de recolhimento, da progressão de regime e da saída definitiva.

Essas bases de dados constituíam cinco bancos de dados distintos, cada qual com uma data de início, mas que se relacionavam a partir de uma chave única: o Registro Geral (RG) do indivíduo. Ou seja, o grande diferencial desses bancos era a possibilidade da sua integração em razão de todos estarem armazenados em plataforma de grande porte e no mesmo computador. Contudo, essa interligação não foi tão simples nem tão rápida, como a princípio os técnicos pensavam, visto que um mesmo indivíduo podia ter diversos inquéritos e processos. Assim, para a ligação do banco de indiciados ao de processados, as chaves complementares foram o número e o ano do inquérito policial; para o banco de processados e para o de executados, o número e o ano do processo criminal. Com isso, garantiu-se um banco final que se referisse a "crimes", e não a "indivíduos".

Em razão do volume de trabalho e da ausência de recursos para que a base de dados deixasse de ser um amontoado de números e se transformasse em algo dotado de significado e de possibilidade de análise, a Fundação Seade, em 2000, propôs um projeto de pesquisa à Fundação de Amparo à Pesquisa do Estado de São Paulo (Fapesp). O objetivo era sistematizar todos os dados, excluindo os registros duplicados e tornando a base de dados mais consistente para a realização de análises sobre o tema.

Com a liberação de recursos e a realização das primeiras análises, os técnicos da Fundação Seade constataram alguns problemas de inconsistência no banco de dados para além da presença dos registros duplicados. Dentre eles, cumpre destacar os seguintes: casos cuja data do crime era posterior à data do inquérito policial e casos que, apesar de estarem na fase judicial, não possuíam correspondência no banco de dados da Polícia Civil. Esses casos foram descartados com o objetivo de garantir que o banco de dados final possuísse apenas informações consistentes sobre o processamento criminal no Estado de São Paulo, de acordo com o delito em questão.

Com a finalização da limpeza do banco de dados, foi definido o recorte temporal da análise. Os pesquisadores optaram por trabalhar com os anos de 1991 a 1998, tomando-se como ano de referência o apontado 
como data do crime pelo inquérito policial. Quanto ao termo inicial, a justificativa apresentada pela Fundação Seade foi a de que os dados anteriores a 1991 não apresentavam um panorama condizente com os prazos da legislação penal atual e, muito menos, com a organização hodierna do sistema de justiça criminal, razão pela qual poderiam alterar a análise. A escolha do ano de 1998 como termo deveu-se à deficiência de informações a partir de 1999, visto que, para esse ano, o banco do Judiciário apresentou perdas de mais de $50 \%$ em relação aos anos anteriores. Portanto, a base de dados final foi resultante do intercâmbio de todas as informações relativas a todos os casos criminais de homicídio cujo processamento fora iniciado em uma das delegacias de Polícia Civil do Estado de São Paulo entre 1991 e 1998.

Esse banco de dados foi cedido a um grupo de pesquisadoras do estudo Metodologia de Tratamento do Tempo e da Morosidade Processual na Justiça Criminal, do Concurso Nacional de Pesquisas Aplicadas em Segurança Pública e Justiça Criminal, realizado pela Secretaria Nacional de Segurança Pública (órgão do Ministério da Justiça) em conjunto com a Associação Nacional de Pós-Graduação e Pesquisa em Ciências Sociais (Anpocs).

Uma vez recebida a base de dados, a pesquisa caminhou no sentido de alcançar uma aderência entre essa base e o fluxograma teórico desenvolvido pela Fundação Seade para o processamento desse delito. O primeiro procedimento adotado foi a rechecagem das seguintes datas (ou momentos críticos): 1) ocorrência; 2) instauração do inquérito policial; 3) início do processo judicial; 4) publicação da sentença definitiva (condenatória ou absolutória); e 5) início do processo de execução.

A partir desse procedimento, foi possível reconstituir o fluxo de processamento do delito de homicídio no âmbito do sistema de justiça criminal paulistano. Foram utilizados os números absolutos em detrimento de taxas e médias, porque apenas dessa forma seria possível representar com fidelidade os graus de filtragem. O resultado final dessa análise pode ser vislumbrado na Figura 2 a seguir.

Do ponto de vista substantivo, essa representação gráfica pode ser entendida como uma medida aproximada da eficiência do sistema de justiça criminal paulistano nos anos 1990. Para interpretá-la, em um primeiro plano, é preciso ter em mente que, quanto maior a perda de casos em cada fase do sistema - desde o registro da ocorrência, perpassando pelo inquérito policial e pelo processo judicial -, maior a sua ineficiência. 
Figura 2

Fluxo de processamento da justiça criminal do Estado de São Paulo

Média do período compreendido entre 1991 e 1998



Fonte: Banco de dados da Fundação Seade - Polícia Civil do Estado de São Paulo e Tribunal de Justiça do Estado de São Paulo.

Assim, a Figura 2 parece indicar que, no processamento dos casos de homicídio registrados entre 1991 e 1998, em uma das delegacias de polícia do Estado de São Paulo, a maior perda de casos ocorre na passagem da fase policial para a fase judicial. Para se ter uma ideia dessa magnitude, apenas 22\% dos casos cujo inquérito policial foi aberto entre 1991 e 1998 resultaram na abertura de um processo penal. Do total de casos registrados pela polícia nesse período, $14 \%$ resultaram em uma sentença.

No intuito de verificar o percentual de esclarecimento (razão entre o número de processos distribuídos e o número de inquéritos policiais iniciados), de sentenciamento (razão entre o número de sentenças proferidas e o número de inquéritos iniciados) e de condenação (razão entre o número de condenações publicadas e o número de inquéritos iniciados) a cada ano, observa-se a Tabela 1. 
Tabela 1

Percentual de esclarecimento, de sentenciamento e de condenação para casos de homicídio cujo processamento teve início e fim no Estado de São Paulo entre 1991 e 1998

\begin{tabular}{l|c|c|c}
\hline Ano & Esclarecimento & Sentenciamento & Condenação \\
\hline 1991 & 28 & 21 & 11 \\
1992 & 29 & 19 & 10 \\
1993 & 26 & 18 & 10 \\
1994 & 23 & 15 & 9 \\
1995 & 22 & 15 & 9 \\
1996 & 20 & 12 & 8 \\
1997 & 16 & 9 & 6 \\
1998 & 13 & 6 & 4 \\
\hline
\end{tabular}

Fonte: Banco de dados da Fundação Seade - Polícia Civil do Estado de São Paulo e Tribunal de Justiça do Estado de São Paulo.

A partir dos dados sumarizados na Tabela 1, é possível verificar que o esclarecimento do caso parece ser o primeiro gargalo. Essas informações denotam ainda que a fase policial parece ser determinante para a continuidade do caso até a fase de sentença. Essa constatação reforça a ideia de que o inquérito policial é uma das fases mais importantes do fluxo do sistema de justiça criminal, uma vez que, caso não ocorra o esclarecimento da autoria ou a prova de materialidade do delito, o caso não pode seguir adiante.

Calculando a diferença entre o percentual de esclarecimento e o percentual de sentenciamento (Gráfico 1), é possível verificar que, ao longo de toda a série, esses percentuais não são substancialmente diferentes. Ou seja, se o caso tem a fase policial completada, é bem provável que ele consiga sobreviver até a fase de sentença.

Por fim, cumpre salientar que a maioria dos casos que ingressaram no sistema de justiça criminal recebeu uma sentença. Esse dado é de extrema importância na medida em que, como bem salienta Cano (2006), por ser o homicídio um crime grave, o processamento deve ser ágil e se encerrar a partir de uma sentença que absolve ou condena o acusado da prática de tal delito. É importante salientar ainda que o percentual encontrado a partir da base de dados da Fundação Seade também não difere do verificado pelas demais pesquisas já realizadas sobre o tema ${ }^{10}$, reforçando, portanto, a ideia de que, se o caso sobrevive à fase 


\section{Gráfico 1}

Diferença entre os percentuais de esclarecimento e sentenciamento para o delito de homicídio cujo processamento teve início e fim no Estado de São Paulo entre 1991 e 1998

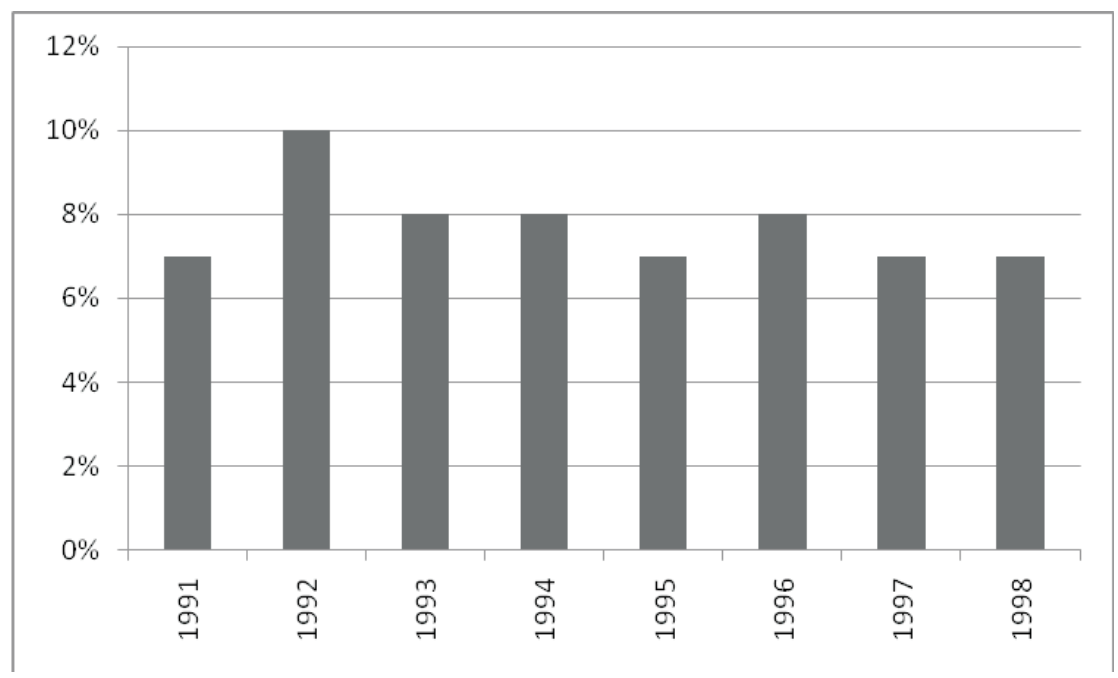

Fonte: Banco de dados da Fundação Seade - Polícia Civil do Estado de São Paulo e Tribunal de Justiça do Estado de São Paulo.

policial, é bem provável que ele seja processado e sentenciado pelo Judiciário.

Uma vez delineado o quadro geral do fluxo do sistema de justiça criminal paulistano para o delito de homicídio no período compreendido entre 1991 e 1998, torna-se indispensável a apresentação das variáveis disponíveis nesse banco de dados (Tabela 2), as quais serão consideradas para a construção de modelos estatísticos capazes de estimar as chances de o caso passar pelas fases de esclarecimento, sentenciamento e condenação.

Os dados sumarizados na Tabela 2 revelam que a maioria dos indivíduos categorizados como autores de um delito de homicídio em São Paulo, no período compreendido entre 1991 e 1998, era do sexo masculino $(96 \%)$, de cor preta ou parda $(40 \%)$ e possuía apenas ensino fundamental (94\%). É interessante notar ainda que os autores do delito de homicídio são essencialmente jovens, possuindo idade média de 29 anos. 
Tabela 2

Variáveis do banco de dados da Fundação Seade consideradas na análise da produção decisória do sistema de justiça criminal do Estado de São Paulo entre 1991 e 1998

\begin{tabular}{|c|c|c|c|c|}
\hline Variáveis & $\mathbf{N}$ & $\begin{array}{l}\text { Valor } \\
\text { mínimo }\end{array}$ & \begin{tabular}{|c|} 
Valor \\
máximo
\end{tabular} & Média \\
\hline O autor do fato é do sexo feminino? & 68.378 & 0,00 - não & $1-\operatorname{sim}$ & 0,04 \\
\hline O réu é negro ou pardo? & 66.759 & $0,00-$ não & $1-\operatorname{sim}$ & 0,40 \\
\hline O réu possui ensino médio ou superior? & 62.998 & $0,00-$ não & $1-\operatorname{sim}$ & 0,06 \\
\hline Há condenação? & 68.378 & 0,00 - não & $1-\operatorname{sim}$ & 0,08 \\
\hline Há flagrante? & 68.378 & 0,00 - não & $1-\operatorname{sim}$ & 0,23 \\
\hline Idade (em anos) & 67.456 & 14 & 88 & 29 \\
\hline Tempo entre o crime e a sentença (em dias) & 9.741 & 13 & 3.736 & 1.011 \\
\hline $\begin{array}{l}\text { Tempo entre a data do crime e o início do } \\
\text { processo (em dias) }\end{array}$ & 14.979 & $1^{11}$ & 3.677 & 761 \\
\hline $\begin{array}{l}\text { Tempo entre o início do processo e a sentença } \\
\text { (em dias) }\end{array}$ & 2.451 & 10 & 2.908 & 517 \\
\hline
\end{tabular}

Fonte: Banco de dados da Fundação Seade - Polícia Civil do Estado de São Paulo e Tribunal de Justiça do Estado de São Paulo.

No que se refere às variáveis processuais, $23 \%$ dos casos foram iniciados a partir de flagrante delito, $8 \%$ resultaram em condenação, e, em média, o tempo de processamento do caso pelo sistema de justiça criminal paulistano foi de 1.011 dias (ou 2,8 anos), sendo a fase mais longa a que transcorre entre a data do crime e a de início do processo (761 dias).

Cabe salientar que as variáveis relativas ao perfil do acusado possuem um número maior de casos válidos do que as variáveis referentes ao tempo de processamento. Em parte, isso ocorre porque, em diversas situações, essas informações não são inseridas pelos operadores do direito quando do manejo dos seus respectivos sistemas de informação. Soma-se a isso o fato de que alguns casos inseridos nessa base de dados podem ainda estar tramitando dentro do sistema e, por isso, não possuir informações completas quanto à data da sentença, por exemplo ${ }^{12}$.

Por outro lado, o fato de essa base contar apenas com as informações sumarizadas na Tabela 2 leva a outra constatação: a precariedade do banco de dados no que diz respeito às informações sobre o perfil da vítima; o relacionamento entre o indiciado e a vítima; o local em que o cri- 
me ocorreu; e a arma empregada na conduta delituosa. Essas informações são indispensáveis para a compreensão tanto dos determinantes do tempo como dos determinantes do desfecho de cada fase do processo de homicídio.

Apesar desses e de outros problemas, essa base de dados se constituiu em uma fonte de informações adequada para a compreensão do fluxo do processamento do delito de homicídio por ser um dos poucos sistemas de informação produzidos a partir das informações fornecidas pelo próprio sistema de justiça criminal. Assim, problemas relativos à ausência de informações sobre variáveis importantes de serem inseridas, como o controle dos modelos estatísticos, são relegados a segundo plano diante da possibilidade de se verificar em que medida as informações oficiais podem ser utilizadas para explicar os determinantes da passagem do caso de uma fase a outra dentro do sistema de justiça criminal.

\section{ANÁLISE DOS DETERMINANTES DE ESCLARECIMENTO, SENTENCIAMENTO E CONDENAÇÃO PARA OS CASOS DE HOMICÍDIO COMPILADOS PELA BASE DE DADOS DA FUNDAÇÃO SEADE}

Para a análise dos determinantes das chances de esclarecimento, sentenciamento e condenação dos casos de homicídio registrados pela Polícia Civil do Estado de São Paulo entre 1991 e 1998, foram construídos três modelos de regressão logística distintos, cada qual referente a um deles.

Os modelos de regressão logística são utilizados quando a variável resposta é dicotômica e as variáveis independentes são categorizadas de forma diferente. Esse tipo de regressão possibilita predizer a variável dependente tendo como base as variáveis independentes, além de determinar a porcentagem da variância da variável resposta explicada pelas covariáveis e o grau da importância relativa das variáveis explicativas. Por fim, esse modelo estima os efeitos de interação, permitindo compreender o impacto da covariação nas variáveis de controle (Soares e Colosimo, 1995).

O problema estatístico que se coloca em modelos como esse é o de encontrar uma expressão elucidativa para o comportamento da probabilidade de sucesso $(p)$ em termos das variáveis explicativas $\left(x_{1}, x_{2}, \ldots x_{\mathrm{K}}\right)$ em comparação com a possibilidade de fracassos. Assim, suponhamos 


\section{Ludmila Ribeiro}

o modelo seguinte, no qual se utiliza apenas uma variável explicativa $x_{1}$ :

$Y=e^{\beta_{0}+\beta_{1} x_{1}}$

Se tomarmos o logaritmo neperiano de (1.0), teremos o seguinte modelo linear:

$\operatorname{Ln}(Y)=\beta_{0}+\beta_{1} x_{1}$

Para o modelo de regressão logística, a grandeza Y é dada por:

$Y=\frac{p}{1-p}$

Dessa forma, tem-se o modelo:

$\operatorname{Ln}\left(\frac{p}{1-p}\right)=\beta_{0}+\beta_{1} x_{1}$

Nesse modelo, o lado esquerdo da equação é denominado logito; a letra $p$ é a probabilidade de ocorrência de um indivíduo ser pobre; o $x$ é a variável explicativa do modelo; e $\beta_{0}$ e $\beta_{1}$ são os parâmetros a serem estimados. Essa expressão representa, assim, o logaritmo da chance. Com isso, o parâmetro do modelo indica a modificação que ocorre no logito dada uma mudança unitária nas variáveis explicativas fixadas no modelo. A razão de chance (odds ratio) mede a força da associação entre um determinado fator e a variável dependente (id., ibid.). Generalizando para um número qualquer de covariáveis, o modelo de regressão logística pode ser escrito da seguinte forma:

$\operatorname{Ln}\left(\frac{p}{1-p}\right)=\beta_{0}+\sum \beta_{1} x_{1}$

A partir das variáveis independentes (ou explicativas) sumarizadas na Tabela 2, pretende-se explicar quais são os fatores que fazem com que o caso perpasse as fases de esclarecimento, sentenciamento e condenação. 


\section{Modelo que Estima as Chances de o Caso Passar da Polícia para o Judiciário}

A Tabela 3 apresenta os resultados do modelo de regressão logística que estima as chances de esclarecimento do delito e, por conseguinte, a possibilidade de início do processo judicial (versus não início do processo). O que se busca verificar, por meio dessa técnica, é a identificação dos fatores que afetam a probabilidade de o caso passar da polícia para o Judiciário.

Tabela 3

Modelo de regressão logística que estima os determinantes do início do processo a partir de sexo, escolaridade, cor da pele e idade do autor do delito, além da existência de flagrante

Sistema de justiça criminal do Estado de São Paulo (1991-1998)

\begin{tabular}{l|c|c|c|c|c|c}
\hline Variável & B & S.E. & Wald & DF & Sig. & Exp(B) \\
\hline Réu de cor preta ou parda & 0,108 & 0,020 & 29,329 & 1 & 0,00 & 1,114 \\
Réu do sexo feminino & $-0,404$ & 0,054 & 54,911 & 1 & 0,00 & 0,668 \\
Réu possui ensino médio ou superior & $-0,334$ & 0,043 & 60,729 & 1 & 0,00 & 0,716 \\
Idade do réu (contínua - em anos) & $-0,012$ & 0,001 & 143,997 & 1 & 0,00 & 0,988 \\
O caso possui flagrante & 0,105 & 0,023 & 21,779 & 1 & 0,00 & 1,111 \\
Constante & $-0,956$ & 0,034 & 809,697 & 1 & 0,00 & 0,384 \\
\hline
\end{tabular}

Fonte: Banco de dados da Fundação Seade - Polícia Civil do Estado de São Paulo e Tribunal de Justiça do Estado de São Paulo.

Nota: Pseudo $\mathrm{R}^{2}=$ 0,06 (mede o quanto de variação na variável resposta é explicado pelo modelo). $\operatorname{Exp}(B):$ Razão de risco na classe.

Utilizando o sexo, a cor, a escolaridade e a idade do autor do delito, bem como a existência ou não do flagrante, é possível explicar $6 \%$ da passagem do caso da polícia para o Judiciário (Pseudo $\mathrm{R}^{2}=0,06$ ). Por outro lado, considerando os coeficientes apresentados por cada uma das variáveis, é possível constatar que:

1. o réu ser de cor preta ou parda aumenta em 1,11 vez as chances de o caso de homicídio passar da polícia para a justiça, em comparação com casos cujo réu é de cor branca;

2. o réu ser do sexo feminino diminui em 0,66 vez as chances de o caso de homicídio passar da fase da polícia para a justiça, em comparação com réus do sexo masculino;

3. o réu possuir ensino médio ou superior diminui em 0,71 vez as chances de o caso de homicídio passar da fase da polícia para a fase 
da justiça, em comparação com réus analfabetos ou com ensino primário;

4. para cada ano que o réu possui a mais, a partir da idade de 14 anos, as chances de o caso passar da polícia para a justiça são diminuídas em 0,98 vez.

Por fim, a única variável processual inserida no modelo (flagrante) aumenta em 1,11 vez as chances de o caso passar da fase da polícia para a justiça.

Em conjunto, esses resultados parecem indicar que réus do sexo masculino, de cor escura, jovens, com baixa instrução e cujo inquérito para investigação do homicídio tenha sido iniciado na polícia a partir de flagrante possuem mais chances de terem um processo iniciado do que réus do sexo feminino, de cor branca, mais velhos e com elevada instrução.

Esses resultados reforçam a noção de que o sistema de justiça criminal brasileiro parece ser mais severo com homens jovens, de cor escura e com baixa escolaridade. Da mesma forma, tal como esperado, o flagrante aumenta as chances de essa passagem (da polícia para o Judiciário) se realizar. Nessas situações, a investigação é mais fácil de ser realizada, já que todos os elementos necessários para comprovação de autoria e a materialidade do delito estão prontamente disponíveis para os policiais. Em situações como essa, o início do processo tende a ser entendido como regra, já que não há dúvidas de que foi o acusado quem realizou o crime do qual está sendo acusado.

\section{Modelos que Estimam as Chances de o Caso Ser Sentenciado}

Uma vez que o caso se insere no Judiciário, a segunda fase crítica, do ponto de vista do fluxo de procedimentos e de pessoas no âmbito do sistema de justiça criminal, é a sentença. Assim, a Tabela 4 apresenta os resultados encontrados a partir da estimativa de um modelo de regressão logística que estima as chances de sentença versus não sentença. O que se buscou verificar com o uso dessa técnica foi a identificação dos fatores que afetam a probabilidade de a sentença ocorrer, dado que o caso foi iniciado no Judiciário. Nesses termos, para a estimativa desse modelo, os casos não iniciados no Judiciário foram excluídos da análise. 


\section{Tabela 4}

Modelo de regressão logística que estima os determinantes da sentença (dado que o processo foi iniciado) a partir de sexo, grau de escolaridade, cor da pele e idade do autor do delito, bem como a existência de flagrante Sistema de justiça criminal do Estado de São Paulo (1991-1998)

\begin{tabular}{l|c|c|c|c|c|c}
\hline Variável & B & S.E. & Wald & DF & Sig. & Exp(B) \\
\hline Réu de cor preta ou parda & 0,098 & 0,046 & 4,492 & 1 & 0,034 & 1,103 \\
Réu do sexo feminino & $-0,084$ & 0,137 & 0,375 & 1 & 0,540 & 0,920 \\
Réu possui ensino médio ou superior & 0,020 & 0,105 & 0,038 & 1 & 0,846 & 1,021 \\
Idade do réu (contínua - em anos) & $-0,013$ & 0,003 & 22,121 & 1 & 0,000 & 0,987 \\
O caso possui flagrante & 0,276 & 0,051 & 29,515 & 1 & 0,000 & 1,318 \\
Constante & $-1,321$ & 0,083 & 253,324 & 1 & 0,000 & 0,267 \\
\hline
\end{tabular}

Fonte: Banco de dados da Fundação Seade - Polícia Civil do Estado de São Paulo e Tribunal de Justiça do Estado de São Paulo.

Nota: Pseudo $\mathrm{R}^{2}=0,04$ (mede o quanto de variação na variável resposta é explicado pelo modelo). $\operatorname{Exp}(B):$ Razão de risco na classe.

Utilizando sexo, cor, idade e escolaridade do autor do delito, bem como a existência ou não do flagrante, é possível explicar $4 \%$ das possibilidades de o caso receber uma sentença, uma vez que este se inseriu no Judiciário. De acordo com as informações sumarizadas na Tabela 4, é possível afirmar ainda que a sentença não pode ser explicada nem pelo sexo nem pelo grau de escolaridade que o indivíduo possui, visto que essas variáveis não aparecem como estatisticamente significantes nesse modelo. Por outro lado, cor, flagrante e idade denotaram as seguintes relações causais com a sentença:

- o réu ser de cor preta aumenta em 1,10 vez as chances de o caso de homicídio ser sentenciado, em comparação a casos cujo réu é de cor branca;

- a idade do réu, para cada ano superior a 14 anos de idade, diminui em 0,98 vez as chances de o caso de homicídio ser sentenciado, uma vez que ele foi incluído no Judiciário;

- o caso possuir flagrante aumenta em 1,31 vez as chances de o caso de homicídio ser sentenciado, em comparação com casos que não possuem flagrante.

Esses resultados apontam para a seguinte situação: se sexo e grau de escolaridade explicam a probabilidade de o caso passar da polícia para o Judiciário, essas mesmas variáveis parecem não ter influência nas chances de o caso, uma vez inserido no Judiciário, receber uma senten- 
ça. Por outro lado, a cor da pele do réu, a idade e o flagrante são variáveis que determinam tanto a primeira passagem como a segunda. Isso significa que essas três últimas variáveis parecem ser indispensáveis para a compreensão de como o fluxo de procedimentos e de pessoas no caso do delito de homicídio se configurava no Estado de São Paulo entre 1991 e 1998.

\section{Modelos que estimam as chances de o caso receber uma condenação}

A Tabela 5 apresenta os resultados do modelo de regressão logística que procura explicar as chances de condenação, dado que o caso de homicídio se inseriu no Judiciário paulistano e foi sentenciado por este entre 1991 e 1998.

\section{Tabela 5}

Modelo de regressão logística que estima os determinantes da condenação (dado que o processo foi iniciado e sentenciado) a partir de sexo, grau de escolaridade, cor da pele e idade do autor do delito, bem como a existência de flagrante Sistema de justiça criminal do Estado de São Paulo (1991-1998)

\begin{tabular}{l|c|c|c|c|c|c}
\hline Variável & B & S.E. & Wald & DF & Sig. & Exp(B) \\
\hline Réu de cor preta ou parda & 0,252 & 0,096 & 6,886 & 1 & 0,009 & 1,286 \\
Réu do sexo feminino & 0,729 & 0,337 & 4,689 & 1 & 0,030 & 2,073 \\
Réu possui ensino médio ou superior & 0,151 & 0,219 & 0,472 & 1 & 0,492 & 1,163 \\
Idade do réu (contínua - em anos) & $-0,026$ & 0,005 & 25,156 & 1 & 0,000 & 0,974 \\
O caso possui flagrante & $-0,014$ & 0,104 & 0,018 & 1 & 0,894 & 0,986 \\
Constante & 1,593 & 0,162 & 97,159 & 1 & 0,000 & 4,921 \\
\hline
\end{tabular}

Fonte: Banco de dados da Fundação Seade - Polícia Civil do Estado de São Paulo e Tribunal de Justiça do Estado de São Paulo.

Nota: Pseudo $\mathrm{R}^{2}=$ 0,17 (mede o quanto de variação na variável resposta é explicado pelo modelo). $\operatorname{Exp}(B):$ Razão de risco na classe.

De acordo com a Tabela 5, utilizando sexo, cor, idade e escolaridade do autor do delito, bem como a existência ou não do flagrante, é possível explicar $17 \%$ da probabilidade de condenação à pena privativa de liberdade. Esses resultados apontam que a condenação não pode ser explicada nem pelo grau de escolaridade que o indivíduo possui nem pela existência de flagrante, pois essas variáveis não apareceram como estatisticamente significantes nesse modelo. Por outro lado, cor, sexo e idade do réu denotaram as seguintes relações causais com a condenação: 
- o réu ser de cor preta ou parda aumenta em 1,28 vez as chances de o caso de homicídio ser condenado (uma vez que ele foi iniciado e sentenciado na justiça), em relação a casos que possuem réus de cor branca;

- o réu ser do sexo feminino aumenta em 2,07 vezes as chances de o caso de homicídio ser condenado (uma vez que ele foi iniciado e sentenciado na justiça), em relação a casos que possuem réus do sexo masculino;

- a idade do réu, para cada ano superior a 14 anos de idade, diminui em 0,97 vez as chances de o caso de homicídio ser condenado, dado que o processo foi iniciado e sentenciado.

Portanto, do ponto de vista substantivo, esses resultados apontam que a condenação parece estar muito mais relacionada às características físicas do indivíduo do que à existência de um conjunto probatório que forneça os elementos reais de autoria e de materialidade do fato. Um indício consistente de que essa afirmação parece se aplicar apenas a essa fase é o fato de que, tão somente nesse modelo, a presença de flagrante não se consubstanciou como variável estatisticamente significante para a realização dessa transição.

\section{Conclusões Gerais para Todos os Modelos}

Para compreender o fluxo de procedimentos e de pessoas no caso do delito de homicídio cujo processamento teve lugar no Estado de São Paulo entre 1991 e 1998, foram criados três modelos logísticos que procuravam estimar as chances de o caso fazer a transição para a fase subsequente, visto que ele fez a transição anterior. A escolha desse tipo de abordagem esteve relacionada à constatação operada por meio da análise da Figura 2, a qual indica que cada fase crítica do fluxo da justiça criminal (início do processo, sentença e condenação) origina bifurcações que denotam que, em vez de o caso seguir em um contínuo, pode percorrer trajetórias distintas, fazendo com que o fluxo seja representado por uma árvore em detrimento de uma linha.

Assim, a Figura 2 denota que cada transição que o caso de homicídio pode fazer dentro do sistema de justiça criminal implica ainda o desafio correspondente de fazer a transição seguinte. Dito de outra forma: se o caso é registrado pela polícia, tem-se o desafio de aquele ter o seu inquérito iniciado; se o inquérito é iniciado, tem-se o desafio de o caso ter a autoria esclarecida; se a autoria é esclarecida, por sua vez, tem-se 
o desafio de o caso se inserir no Judiciário. Já no âmbito deste, a próxima barreira a ser vencida é a sentença.

Os modelos que procuraram estimar, de maneira condicionada, as chances de o caso ter sua autoria esclarecida, ser sentenciado e receber uma condenação evidenciaram que a cor do réu e a idade são os elementos que parecem condicionar todas as transições. Isso porque as demais variáveis analisadas (sexo, grau de escolaridade e flagrante) foram importantes para a explicação de algumas transições, mas não de todas.

Os três modelos logísticos denotaram ainda que os réus jovens de cor preta e parda são aqueles que, em comparação com indivíduos mais velhos e de cor branca, possuem mais chances de percorrer todo o fluxo do sistema de justiça criminal: desde o registro do delito pela Polícia Civil até a condenação. Isso porque, nos três modelos estatísticos construídos, essas foram as variáveis que se apresentaram como estatisticamente significantes para explicar a possibilidade de passagem de uma fase a outra no âmbito do fluxo do sistema de justiça criminal.

Assim, pode-se afirmar que o maior mérito do presente estudo é contribuir para um melhor entendimento de como as características dos envolvidos no crime de homicídio se sobrepõem às características processuais e legais do caso, fazendo com que a continuidade deste no fluxo seja determinada não pela característica do crime, mas pela do próprio criminoso.

Esses resultados corroboram, por sua vez, os encontrados em outras pesquisas sobre o tema. Por exemplo: no início dos anos 1990, Adorno (1994) conduziu uma pesquisa que procurava testar a hipótese amplamente difundida nos estudos criminológicos norte-americanos de que a justiça penal é mais rigorosa com réus negros do que com réus brancos. Analisando todos os crimes violentos de competência dos tribunais singulares (roubo, tráfico de drogas, latrocínio, tráfico qualificado, estupro) ocorridos no município de São Paulo e julgados em primeira instância no ano de 1990, o autor pôde constatar que havia maior incidência de prisões em flagrante para réus negros (58,1\%), comparativamente a réus brancos $(46,0 \%)$, apesar de, na época, existir maior proporção de réus brancos respondendo a processo em liberdade $(27,0 \%)$, comparativamente a réus negros (15,5\%). De acordo com o autor, esses dados pareciam indicar que existe maior vigilância policial sobre a população negra do que sobre a população branca. 
Em pesquisa posterior, Adorno (1996) analisou os casos de roubo qualificado também julgados em São Paulo no ano de 1990, mas do ponto de vista da distribuição das sentenças judiciais para crimes de idêntica natureza cometidos por ambas as categorias de cidadãos (negros e pardos versus brancos). Com isso, o autor pôde constatar que, no desfecho processual, há maior proporção de réus negros condenados $(68,8 \%)$ do que de réus brancos $(59,4 \%)$. A absolvição favorece preferencialmente réus brancos $(37,5 \%)$, comparativamente a réus negros $(31,2 \%)$.

Contudo, é importante destacar que a ausência de variáveis como o perfil da vítima, a arma utilizada para a realização do homicídio e ainda a relação entre autor e vítima faz com que a generalização desses resultados ocorra com bastante cautela. Ou seja, apesar de os resultados sumarizados nas Tabelas 3, 4 e 5 serem importantes para uma melhor compreensão dos determinantes das transições que se operam ao longo do fluxo de processamento da justiça criminal, eles devem ser entendidos como ponto de partida para coleta de informações nos processos judiciais e ainda para análises subsequentes que procurem compreender com maior profundidade esse fenômeno. Tal ressalva é importante, visto que tais modelos carecem de outras variáveis importantes para o entendimento do fenômeno e, ainda, por essas análises serem baseadas em uma base de dados que, apesar da sua relevância, possui os vícios de origem relacionados aos sistemas de informação oficiais.

\section{CONSIDERAÇÕES FINAIS}

A citação abaixo, de Thompson (1983), resume com propriedade o objetivo deste artigo: analisar a produção decisória do sistema de justiça criminal do Estado de São Paulo para os crimes de homicídio processados entre 1991 e 1998, com o intuito de reconstruir o fluxo de procedimentos para esse delito nesse espaço de tempo e ainda elaborar modelos que permitam a melhor compreensão dos determinantes das taxas de esclarecimento, sentenciamento e condenação dentro de uma ideia de transições condicionais:

Da prática do crime à condenação do autor há um longo caminho a ser percorrido, o qual oferece etapas marcantes, como as seguintes: a) ser o fato relatado à polícia; b) se relatado, ser registrado; c) se registrado, ser investigado; d) se investigado, gerar um inquérito; e) se existente o inquérito, dar origem a uma denúncia por parte do promotor; f) se denun- 


\section{Ludmila Ribeiro}

ciado, redundar em condenação pelo juiz; g) se, havendo condenação e expedido o conseqüente mandato de prisão, a polícia efetivamente o executar. Importante salientar ainda que esta própria citação traz em si o peso da fase policial, que congrega quatro dos oito funis que integram a persecução criminal descrita pelo autor (ibid.:10).

Os dados utilizados foram obtidos a partir de uma base de dados organizada pela Fundação Seade, a qual procurou interligar os sistemas de informação da polícia, do Judiciário e do sistema penitenciário, com o objetivo de verificar os caminhos percorridos pelos casos de homicídio registrados em todas as delegacias de Polícia Civil no Estado de São Paulo entre 1991 e 1998.

Apesar de todos os problemas descritos quanto à qualidade dos dados produzidos oficialmente pelas organizações que compõem o sistema de justiça criminal brasileiro e, ademais, de a base de dados da Fundação Seade também padecer de alguns desses problemas, essa base foi escolhida para análise por possuir, além de informações processuais (presença de flagrante, datas de instauração de inquérito, de sentenças e tipo de decisão), informações sobre o autor desse delito, tais como sexo, idade, escolaridade, raça/cor.

Usando essas informações, o artigo pôde mensurar o número de casos que conseguiram realizar todas as transições necessárias para serem considerados totalmente processados pelo sistema de justiça criminal brasileiro. A partir do cálculo das taxas de esclarecimento, sentenciamento e condenação desse sistema para o delito de homicídio, a análise se voltou para a construção de modelos estatísticos que procuraram compreender o peso das variáveis legais e extralegais na permanência dessas ocorrências no fluxo e para a obtenção de uma decisão condenatória. Essas estratégias permitiram constatar que:

1. O principal gargalo desse fluxo se encontra na passagem da fase policial para a judicial, uma vez que, do total de homicídios registrados pela Polícia Civil, apenas $22 \%$ se transformaram em processos; $14 \%$ alcançaram a fase de sentença; e $8 \%$ resultaram em uma condenação à pena privativa de liberdade. Ou seja, uma vez superada a fase policial, a chance de um homicídio chegar a julgamento é muito maior do que permanecer sem sentença.

2. Os modelos estatísticos de regressão logística podem se consubstanciar em boa estratégia de análise para a melhor compreensão do que ocorre no âmbito do fluxo de processamento de determinado 
delito no sistema de justiça criminal brasileiro. Essas análises são especialmente importantes quando combinam, em uma mesma equação, as características dos indivíduos envolvidos, características legais e processuais do caso, em detrimento de considerar a sobrevivência do caso no fluxo do sistema de justiça criminal como a resultante de apenas um grupo dessas características. Os resultados desses modelos denotaram que as variáveis relacionadas ao perfil dos acusados, tais como cor e idade, possuem maior peso na explicação da decisão de manter a ocorrência criminal, viabilizando a sua sobrevivência a todas as fases que compõem o fluxo, influenciando ainda a decisão condenatória. As outras variáveis analisadas - sexo, escolaridade e flagrante-apresentaram peso variável conforme a etapa analisada.

Portanto, considerando os casos de homicídio processados pela justiça do Estado de São Paulo entre 1991 e 1998, é possível afirmar que réus jovens de cor preta e parda ainda são mais discriminados pelo sistema de justiça criminal. Tal constatação denota que, apesar de os sistemas de justiça criminal terem sido concebidos para processar o delito (e não o indivíduo) utilizando-se apenas as informações relativas à natureza do caso, esse ainda não parece ser um exemplo do que ocorre no cenário brasileiro.

Por fim, cumpre destacar que o acesso a dados que permitam uma pesquisa de maior abrangência sobre o funcionamento do sistema de justiça criminal esbarra, no caso brasileiro, na sua sofrível qualidade, nas dificuldades de obtenção e de temporalidade para análise. No entanto, estudos dessa natureza são fundamentais para entender as diversas dinâmicas dos atores envolvidos no sistema, até mesmo para que seja possível a proposição de reformas que resultem na configuração de um fluxo estruturado mais a partir de variáveis legais do que de extralegais.

(Recebido para publicação em março de 2009)

(Versão definitiva em dezembro de 2009) 


\section{Ludmila Ribeiro}

\section{NOTAS}

1. Importante salientar que, apesar de o título da figura ser Sistemática de funcionamento da justiça criminal brasileira, esse é o sistema vigente em cada um dos estados-membros, pois, como o Brasil adotou o modelo federativo de organização do seu Estado, além do Sistema de Justiça Estadual, há o Sistema de Justiça Federal, com suas próprias organizações. A grande diferença entre esses, para além da competência (que é dada pelo local e pela natureza da infração), é a inexistência, no âmbito federal, de duas organizações policiais. Nessa seara, há apenas a Polícia Judiciária da União, que é a Polícia Federal. As atividades ostensivas, nesse caso, também ficam a cargo das polícias militares dos estados-membros e, por conseguinte, muitas vezes, a porta de entrada no sistema de justiça criminal da União termina por ser a própria Polícia Militar.

2. Caso o crime seja de competência dos Juizados Especiais Criminais (crimes cuja pena máxima não seja superior a dois anos), é possível que o caso se encerre por meio de um acordo (transação penal) entre o acusado e o Ministério Público. No entanto, como os homicídios não se encaixam nessa categoria, por possuírem pena máxima de vinte anos, essas instâncias não foram analisadas neste artigo.

3. Para uma análise dos estudos sobre fluxo do sistema de justiça criminal já produzidos no Brasil, consultar Ribeiro (2009).

4. Desde o ano de 2000, esse sistema vem sendo progressivamente melhorado (em termos de qualidade da informação produzida), em razão dos investimentos constantes do Ministério da Justiça nessa seara.

5. Vale destacar que a reforma do CPP, ocorrida em 2008, determinou a concentração dessas diversas audiências para oitiva de testemunhas e interrogatório do réu em uma única audiência. Contudo, como esta pesquisa foi realizada antes do advento de tal legislação, a linha de fluxo representada está de acordo com o vigente na época em que os dados foram coletados.

6. Tal como destacado por Batista (2007), a pronúncia é uma decisão interlocutória mista, que põe fim à fase instrutória sem julgar o mérito da ação penal - possui formalmente a estrutura de uma sentença, ou seja, deve ter relatório, fundamentação e dispositivo (art. 381 do CPP). Diferencia-se, contudo, particularmente quanto à quaestio juris - ou seja, a plausibilidade de se levar um cidadão ao julgamento popular -, devendo, nesse aspecto, dispor obrigatoriamente sobre a justa causa da acusação (prova da materialidade do crime e indícios de autoria - lastro probatório mínimo) e, quando necessário, sobre os fatos que qualificam o crime.

7. Essa ressalva é importante porque, tal como destacado na subseção anterior, crimes distintos podem suscitar formatos, modelos e tempos de processamento diferenciados. Dessa forma, apenas se pode compreender e comparar fluxos de processamento tendo como base crimes semelhantes.

8. Ainda hoje o Brasil não preenche esse formulário sob o argumento de que não possui tais informações.

9. Gostaria de registrar agradecimento à Fundação Seade, especialmente ao doutor Renato Sérgio de Lima, que, gentilmente, cedeu a base de dados sem a qual este estudo não poderia ter sido realizado. Agradeço ainda os seus comentários sobre a análise dessa fonte de informações que contribuíram para a versão final deste artigo. 
10. Para uma análise mais detalhada, ver Ribeiro (2009).

11. A possibilidade de um processo penal ter sido aberto no mesmo dia, apesar de remota, pode acontecer especialmente em casos que envolvem grande pressão da mídia e flagrante. Nesse sentido, apesar de suspeito, esse caso foi considerado válido para fins desta análise.

12. Não foi possível ter acesso ao desfecho desses casos após a base de dados ter sido repassada à pesquisa.

\section{REFERÊNCIAS BIBLIOGRÁFICAS}

ADORNO, Sérgio. (1994), “Crime, Justiça Penal e Desigualdade Jurídica. Os Crimes que se Contam no Tribunal do Júri”. Revista USP, vol. 21, pp. 132-151.

. (1996), “Racismo, Criminalidade Violenta e Justiça Penal: Réus Brancos e Negros em Perspectiva Comparativa". Estudos Históricos, vol. 9, no 18, pp. 283-300.

e IZUMINO, Wânia Pazinato. (2000), "Fontes de Dados Judiciais", in D. Cerqueira, J. Lemgruber e L. Musumeci (orgs.), Fórum de Debates: Criminalidade, Violência e Segurança Pública no Brasil: Uma Discussão sobre as Bases de Dados e Questões Metodológicas. Rio de Janeiro, Ipea/Cesec.

ANDRADE, Mônica Veigas, PEIXOTO, Betânia Totino e MORO, Sueli. (2003), "Criminalidade na Região Metropolitana de Belo Horizonte: Uma Análise Espacial”. Anais do XXV Encontro Brasileiro de Econometria. Porto Seguro, SBE.

AZEVEDO, Rodrigo Ghiringhelli de. (2008), Segurança Pública e Justiça Penal no Brasil. Cadernos Adenauer, ano 9, no 4.

BATISTA, Fernando Natal. (2007), “A Fragmentariedade da Sentença de Pronúncia”. Jus Navigandi, Teresina, ano 11, no 1.335 .

BATITUCCI, Eduardo Cerqueira. (2008), “As Limitações da Contabilidade Oficial de Crimes no Brasil: O Papel das Instituições de Pesquisa e Estatística". São Paulo em Perspectiva, vol. 21, pp. 7-18.

CANO, Ignacio. (2006), “Mensurando a Impunidade no Sistema de Justiça Criminal do Rio de Janeiro". Anais do III Congresso Latino-Americano de Ciência Política: Democracia e Desigualdades. Campinas, Unicamp.

LEMGRUBER, Julita T., CERQUEIRA, Daniel e MUSUMECI, Leonarda. (2000), “O Sistema Penitenciário Brasileiro", in D. Cerqueira, J. Lemgruber L. e Musumeci, Fórum de Debates: Criminalidade, Violência e Segurança Pública no Brasil: Uma Discussão sobre as Bases de Dados e Questões Metodológicas. Rio de Janeiro, Ipea/Cesec-Ucam.

LIMA, Renato Sérgio de. (2005), Contando Crimes e Criminosos em São Paulo: Uma Sociologia das Estatísticas Produzidas e Utilizadas entre 1871 e 2000. Tese de doutorado em Sociologia, Departamento de Sociologia, Universidade de São Paulo, São Paulo. 


\section{Ludmila Ribeiro}

MISSE, Michel e VARGAS, Joana Domingues. (2007), “O Fluxo do Processo de Incriminação no Rio de Janeiro na Década de 50 e no Período 1997-2001: Comparação e Análi$\mathrm{se}^{\prime \prime}$. Anais do XIII Congresso Brasileiro de Sociologia. Recife, UFPE.

RIBEIRO, Ludmila. (2009), “Impunidade no Sistema de Justiça Criminal Brasileiro: Uma Revisão dos Estudos Produzidos sobre o Tema". Research Paper Series, 48, Latin American and Iberian Institute (LAII). New Mexico, University of New México.

SAPORI, Luís Flávio. (1995), "A Administração da Justiça Criminal numa Área Metropolitana". Revista Brasileira de Ciências Sociais, vol. 10, № 29. . (2007), Segurança Pública no Brasil: Desafios e Perspectivas. Rio de Janeiro, Editora FGV.

SOARES, José Francisco e COLOSIMO, Enrico Antônio. (1995), "Métodos Estatísticos na Pesquisa Clínica". Anais da XL Reunião Anual da Região Brasileira da Sociedade Internacional de Biometria. Ribeirão Preto, USP.

THOMPSON, Augusto Frederico G. (1983), Quem São os Criminosos? Rio de Janeiro, Achiamé.

TOURINHO FILHO, Fernando da Costa. (2001), Curso de Processo Penal. Saraiva, São Paulo.

VARGAS, Joana Domingues. (2007), “Análise Comparada do Fluxo do Sistema de Justiça para o Crime de Estupro". DADOS, vol. 50, no 4, pp. 671-697.

e RIBEIRO, Ludmila. (2008), “Estudos de Fluxo da Justiça Criminal: Balanço e Perspectivas". Anais do XXXII Encontro Anual da Anpocs. Caxambu, Anpocs. 


\begin{abstract}
Prosecution for Murder in the Criminal Justice System: An Analysis of Data from the State of São Paulo for the Years 1991 to 1998
\end{abstract}

The aim of this article is to analyze how the São Paulo criminal justice system handles homicide cases reported through the State's police precincts (from 1991 to 1998) and the respective law enforcement and legal ramifications. The data were obtained from the Seade Foundation database. Using this information, the study showed that non-legal variables like color and age play a key role in understanding the system's rulings and sentences in murder cases.

Key words: criminal justice system; crime-solving rate; turnover rate; sentencing rate; conviction rate; prosecution for murder

\title{
RÉSUMÉ
}

La Production Décisoire du Système de Justice Pénale pour le Crime d'Homicide: Analyse des Données de l'État de São Paulo pour la Période 1991-1998

Dans cet article, on examine le fonctionnement du système de justice pénale dans l'État de São Paulo avec pour base les homicides répertoriés dans les commissariats de police pendant la période 1991-1998, ainsi que leurs conséquences policières et judiciaires. On s'est servi des données fournies par le système d'information établi par la Fondation Seade. À partir de ces renseignements, on a pu voir que des variables extra-légales, comme la couleur de peau et $\mathrm{l}^{\prime}$ âge, jouent un rôle primordial dans la compréhension de la production décisoire du système de justice pénale concernant le délit d'homicide.

Mots-clé: système de justice pénale; taux d'élucidation; taux de procédures; taux de sentences; taux de condamnations; fréquence du crime d'homicide 